\title{
Structural Analysis of Powdered Manganese(II) of 1,10-Phenanthroline (phen) as Ligand and Trifluoroacetate (TFA) as Counter anion
}

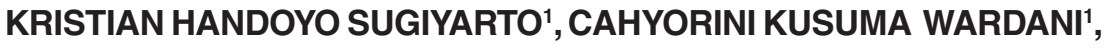 \\ HARI SUTRISNO' ${ }^{1}$ and MUHAMMAD WAHYU ARIF WIBOWO ${ }^{1}$
}

Department of Chemistry Education, Yogyakarta State University, Indonesia.

*Corresponding author: sugiyarto@uny.ac.id

http://dx.doi.org/10.13005/ojc/340216

(Received: December 21, 2017; Accepted: March 01, 2018)

\begin{abstract}
The complex containing manganese(II), 1,10-phenanthroline (phen) as ligand and trifluoroacetate (TFA) as counter anion has been prepared and characterized. The electrical equivalent conductance, metal content, and TGA-DTA analysis suggests the complex to be $\left[\mathrm{Mn}(\text { phen })_{3}\right](\mathrm{TFA})_{2} \cdot 1 \cdot 35 \mathrm{H}_{2} \mathrm{O}$. The magnetic moment was found to be normal high-spin paramagnetic for 5 unpaired electrons in the electron configuration of manganese(II). The electronic spectral bands indicates the five posible spin-forbidden transitions of sextet ground state to quartet excited states. The IR spectral data signify the mode of vibrations typical for phenanthroline as well as TFA, while the images of SEM-EDX photographs confirm the existence of the coresponding elemental content, they reflect high crystalinity of the complex as evidence of the sharp peaks of the corresponding powdered diffractogram. The analysis of powder XRD refined by Le Bail program was found to be structurally triclinic symmetry of $P$ I for the cationic complex with the cell parameters of $a=13.6422 \AA ; b=18.2792 \AA ; c=23.8741 \AA \alpha=114.4245^{\circ} ; \beta=94.8337^{\circ} ; \gamma$ $=99.7977^{\circ} ; V=5261.6714 \AA^{3}, Z=1 ;$ with figure of merit: $R_{p}=1.31 ; R_{w p}=2.39 ; R_{\text {exp }}=0.56 ;$ Bragg R-Factor $=0.04$; and GOF $=18.00$.
\end{abstract}

Keywords: Phenathroline, Manganese(II), Trifluoroacetate, Rietica, Le Bail analysis.

\section{INTRODUCTION}

Synthesis and characterisation of complexes which were composed of transition metals, phenanthroline (phen) as ligand, and various counter ions, $\mathrm{NO}_{3}^{-}, \mathrm{BF}_{4}^{-}, \mathrm{ClO}_{4}^{-}, \mathrm{PF}_{6}^{-}$have been reported long time ago ${ }^{1-2}$. However, the cell parameters of a single crystal of tris(phenanthroline) manganese(II) cation with any counter anion is, in fact, not easy to confirm, meaning that the preparation of single crystals seem unsuccessful. The chemistry of supramolecular tris(phenanthroline) 
manganese(II) cation has been reported to associate with $\mathrm{I}_{3}{ }^{-}$and $\mathrm{I}_{5}{ }^{-}$ions in the single crystals of $\left[\mathrm{Mn}(\text { phen })_{3}\right]\left(\mathrm{I}_{3}\right)_{2}{ }^{3}$ and $\left[\mathrm{Mn}(\text { phen })_{3}\right]_{8} \mathrm{I}_{8}$. Quite recently, the single crystal of simple perchlorate anion of $\left[\mathrm{Mn}(\text { phen })_{3}\right]^{2+}$ was isolated, but it was also known together with carbonic acid 5 .

Trifluoroacetic acid, H-TFA, is known a strong acid. The corresponding $p K a$ is about 0.23 compared to a pKa of 4.76 for the acetic acid and thus being about 100,000 times stronger ${ }^{6}$. It is associated with the strongest electronegativity of fluorine atoms which leads to the electronwithdrawing character of the trifluoromethyl group. This results in weakening the oxygen-hydrogen bond and therefore stabilising the conjugate base of anion. Thus, it might be considered in the same group of strong acids with $p K a$ less than one, such as hydroiodic, hydrobromic, hydrochloric, perchloric, chloric, nitric and (mono)sulfuric acids ${ }^{7}$.

For these reasons, the TFA would be possible to be a counter anionic role in cationic complex synthesis. However, the $3 d$ cationic transition complex of TFA has not been much observed, and it seems the only cationic mercuracycle was reported ${ }^{8}$. In fact the monodentate coordinated TFA to gold (I) ${ }^{9}$ and to cobalt(II) ${ }^{10}$ in a polymer complexes were observed. Complex of diisopropylammonium triûuoroacetate has also been synthesized and found to be monodentate coordinated TFA with hydrogen bonding of $\mathrm{N}-\mathrm{H} \cdot \ldots \mathrm{O}^{11}$. With transition metals, $\mathrm{Ru}$, Os, and $\mathrm{Ir}$, hydrogen bonding of TFA were produced ${ }^{12}$. With the monodentate ligand of pyridine $(p y)$, some molecular complexes of $\mathrm{M}(\mathrm{Py})\left(\mathrm{CF}_{3} \mathrm{CO}_{2}\right)$ where $\mathrm{M}=\mathrm{Co}(\mathrm{II}), \mathrm{Ni}(\mathrm{II})$, and $\mathrm{Cu}(\mathrm{II})$, were isolated, indicating the coordinated TFA as a ligand rather than counter anion ${ }^{13}$.

The previous works clearly involved monodentate organic ligands, and it is readily understood that the TFA might prefer to coordinate as anionic ligand also. Thus, by involving relatively strong coordinated bidentate ligand such as 1,10-phenanthroline, the tendency of TFA to be mono/bi-dentate anionic ligand might be reduced and a cationic complex should result.
Thus the synthesis of manganese(II) complex of phenantroline and TFA anion should be useful in understanding the ionic-molecular characteristic of the complex. The powder-XRD of the complex may be refined following Rietica method and this should lead to the structural lattice parameters, being comparable to some known single crystal structures as for example described by Polyanskaya et al., ${ }^{14}$ and Wang $^{15}$, and it is the main idea of this work. In the last two complexes the corresponding magnetic moment and electronic spectral data have not been reported yet.

\section{EXPERIMENTAL}

\section{Materials}

The main chemicals, nickel nitrate hexahydrate $\left(\mathrm{Ni}\left(\mathrm{NO}_{3}\right)_{2} \cdot 6 \mathrm{H}_{2} \mathrm{O}\right), 1,10$-phenanthroline $\left(\mathrm{C}_{12} \mathrm{H}_{8} \mathrm{~N}_{2}\right)$, sodium trifluoroacetate $\left(\mathrm{CF}_{3} \mathrm{COONa}\right)$, calcium nitrate $\left(\mathrm{Ca}\left(\mathrm{NO}_{3}\right)_{2}\right)$, nickel sulfate $\left(\mathrm{NiSO}_{4}\right)$, calcium chloride $\left(\mathrm{CaCl}_{2}\right)$, ammonium nitrate $\left(\mathrm{NH}_{4} \mathrm{NO}_{3}\right)$, aluminium nitrate $\left(\mathrm{Al}\left(\mathrm{NO}_{3}\right)_{3} \cdot 6 \mathrm{H}_{2} \mathrm{O}\right)$, and iron(III) chloride $\left(\mathrm{FeCl}_{3}\right)$ were purchased from Sigma-Aldrich. All the reagents were used without further purification.

\section{Preparation of Tris(phenantroline)manganese(II) Trifluoroacetate}

The mixture of about $5 \mathrm{~mL}$ solution of 0.32 mol phenanthroline in water with three drops of ethanol to clearly dissolve and about $10 \mathrm{~mL}$ of an aqueous solution of $0.1 \mathrm{~mol} \mathrm{Mn}\left(\mathrm{NO}_{3}\right)_{2}$ was warmed while well stiring to obtain a homogeneous solution. A saturated aqueous solution of $\mathrm{CF}_{3} \mathrm{COONa}(0.4$ $\mathrm{mol}$ in $5 \mathrm{~mL}$ ) which was stoichiometrically in excess was added to the mixture. It was then concentrated on heating, and the powdered complex which was precipitated on scratching while cooling was filtered, washed with a minimum of cold water, and then let the precipitate dry in exposure.

\section{Physical Characterization}

Magnetism. The magnetic moment of the complex was calculated through the measurement of the susceptibility for powdered samples which were obtained on magnetic susceptibility balance of Auto Sherwood Scientific 240V-AC model. This was calibrated with $\mathrm{CuSO}_{4} \cdot 5 \mathrm{H}_{2} \mathrm{O}$. The corrected diamagnetism using Pascal's constant ${ }^{16}$ was applied to the molar magnetic susceptibility data 
on the calculation of effective magnetic moment $\left(\mu_{\text {eff }}\right)$ following the formula, $\mu_{\text {eff }}=2.828 \sqrt{ }\left(X_{M} \cdot T\right) B M$.

IR and UV-Vis Spectra. The IR spectrum of the sample which was set on the cell with potassium bromide pellets was recorded on a FTIR Spectrophotometer ABB MB3000 at $500-4000 \mathrm{~cm}^{-1}$. UV-Vis spectrum of the powdered complex was recorded on a spectrophotometer of Pharmaspec UV 1700. The powders were spread on a thin glass adhered with ethanol. It was then put in the cell holder and the spectrum was recorded at 200-1000 $\mathrm{nm}$. The spectrophotometer UV-V is Shimadzu 2400 PC Series was applied for recording the spectrum of complex in solution.

Ionic Property and Metal Content. The ionic character of the complex was based on the data of equivalent electrical conductance recorded using a conductometer Lutron CD-4301 calibrated with $1.0 \mathrm{M}$ potassium chloride at $25^{\circ}$. The data obtained were compared to those of known ionic solutions, $\mathrm{NH}_{4} \mathrm{NO}_{3}, \mathrm{CaCl}_{2}, \mathrm{Ca}\left(\mathrm{NO}_{3}\right)_{2}, \mathrm{NiSO}_{4}, \mathrm{MnSO}_{4}, \mathrm{FeCl}_{3}$, and $\mathrm{Al}\left(\mathrm{NO}_{3}\right)_{3}$, which were also recorded on the same instrument. The metal content of the complex was etimated as observed by Atomic Absorption Spectrophotometer model of PinAAcle 900T Perkin Elmer.

TGA-DTA (Thermogravimetric Analysis and Differential Thermal Analysis). Thermal decomposition of the complex, $\left[\mathrm{Mn}(\text { phen })_{3}\right]\left(\mathrm{CF}_{3} \mathrm{COO}\right)_{2}$. $1.35 \mathrm{H}_{2} \mathrm{O}$, was performed up to $600{ }^{\circ} \mathrm{C}$ under nitrogen, to confirm the lost of particular materials contained in the compound. Thus, the loss of hydrated molecule of water and decomposition of other materials were performed on Diamond (Perkin Elmer Instruments), and simultaneous TGA-DTA graphs were obtained by a model NETZSCH STA
$409 \mathrm{C} / \mathrm{CO}$ thermal analyzer within the rate of $10^{\circ} \mathrm{C} /$ minutes.

X-Ray Powder Diffraction. The X-ray diffractogram of the powdered complex was collected using a Rigaku Miniflex 60040 kW 15 $\mathrm{mA}$ Benchtop Diffractometer, with CuK $\alpha$ : $\lambda=1.5406$ $\AA$. The powdered complex was spread on the glass plate which was then set on the cell holder. The data of reflection were collected in a scan mode with interval of 0.04 steps per 4 seconds within $2 \mathrm{~h}$ at 2-90 degree of $2 \theta$. The X-Ray diffractogram then was refined according to Rietica program of Le Bail method at the range 5-60 degree of $2 \theta$ which was run within 75 cycles.

SEM-EDX (Scanning Electron Microscopy with Energy Dispersive X-Ray). The SEM images of the complex were recorded in JEOL JED-2300 model to confirm the crystalinity as well as the content of the main elements.

\section{RESULTS AND DISCUSSION}

\section{Conductance, AAS, TGA-DTA and Chemical Formula}

Direct interactions of manganese(II) nitrate and the phenanthroline in solution resulted in a light yellow-greenish solution of cationic complex which precipitated on the addition of excessive TFA salt. The equivalent electrical conductance of this complex was estimated on the basis of known simple compounds, and the results of measurement are listed in Table 1. It was found that the conductance value for the complex is in the range of those for ionic compounds of three ions per molecule, and hence the empirical formula of $\left[\mathrm{Mn}(\text { phen })_{n}\right]\left(\mathrm{CF}_{3} \mathrm{COO}\right)_{2} \cdot \mathrm{xH}_{2} \mathrm{O}$ is then proposed for this complex, indicating a typical uncoordinated anion of TFA.

Table 1: Equivalent electric conductance of the complex and some known salts in aqueous solutions

\begin{tabular}{|c|c|c|c|}
\hline Compounds & $\begin{array}{l}\text { Equivalent conductance } \\
\qquad(\Lambda \mathrm{c}) \Omega^{-1} \mathrm{~cm}^{2} \mathrm{~mol}^{-1}\end{array}$ & $\begin{array}{l}\text { Amount ratio of } \\
\text { cation/anion }\end{array}$ & $\begin{array}{c}\text { Number of ions } \\
\text { per molecule }\end{array}$ \\
\hline $\mathrm{NH}_{4} \mathrm{NO}_{3}$ & 160.429 & $1: 1$ & 2 \\
\hline $\mathrm{NiSO}_{4}$ & 118.355 & $1: 1$ & 2 \\
\hline $\mathrm{MnSO}_{4}$ & 119.612 & $1: 1$ & 2 \\
\hline $\mathrm{Ca}\left(\mathrm{NO}_{3}^{4}\right)_{2}$ & 379.355 & $1: 2$ & 3 \\
\hline $\mathrm{Al}\left(\mathrm{NO}_{3}\right)_{3}$ & 519.095 & $1: 3$ & 4 \\
\hline $\mathrm{FeCl}_{3}$ & 476.975 & $1: 3$ & 4 \\
\hline$\left[\mathrm{Mn}(\text { phen })_{n}\right]\left(\mathrm{CF}_{3} \mathrm{COO}\right)_{2} \cdot x \mathrm{H}_{2} \mathrm{O}$ & 209.125 & $1: 2$ & 3 \\
\hline
\end{tabular}


The metal content observed in the atomic absorption spectral data $(6.9 \%$ in mass) followed by TGA data should estimate the coordination number $(n)$ and the number of hydrates $(x)$ of the empirical formula. As shown in Fig. 1, the mass loss of $2.856 \%$ in the first stage at $80-90{ }^{\circ} \mathrm{C}$ is believed due to the loss of $1.35 \mathrm{H}_{2} \mathrm{O}$ (ca. $2.873 \%$ ). While the loss of mass in the second-third-forth stages are complicated to identify, the residual mass of $18.624 \%$ at $300-500{ }^{\circ} \mathrm{C}$ seems to be due to $\alpha-\mathrm{Mn}_{2} \mathrm{O}_{3}$ (ca. $\left.18.664 \%\right)^{17}$, leading to $\mathrm{Mn}$ content of $6.96 \%$ (ca. $6.50 \%$ ). Theoretically, the mass loss of
TFA and phen are 25.444 and $60.857 \%$, respectively, while total loss in the second-forth stages $\left(150-400{ }^{\circ} \mathrm{C}\right)$ is only about $78.52 \%$. The only thing we can say is that during the loss of TFA, the oxygen atom might react with metal to form final product of $\mathrm{Mn}_{2} \mathrm{O}_{3}$.

Thus in summary, the percentage of each entity in the powdered complex as shown in Table 2 might confirm the formula proposed, $\left[\mathrm{Mn}(\text { phen })_{3}\right]\left(\mathrm{CF}_{3} \mathrm{COO}\right)_{2} \cdot 1.35 \mathrm{H}_{2} \mathrm{O}$, as expected also from stoichiometric preparation.

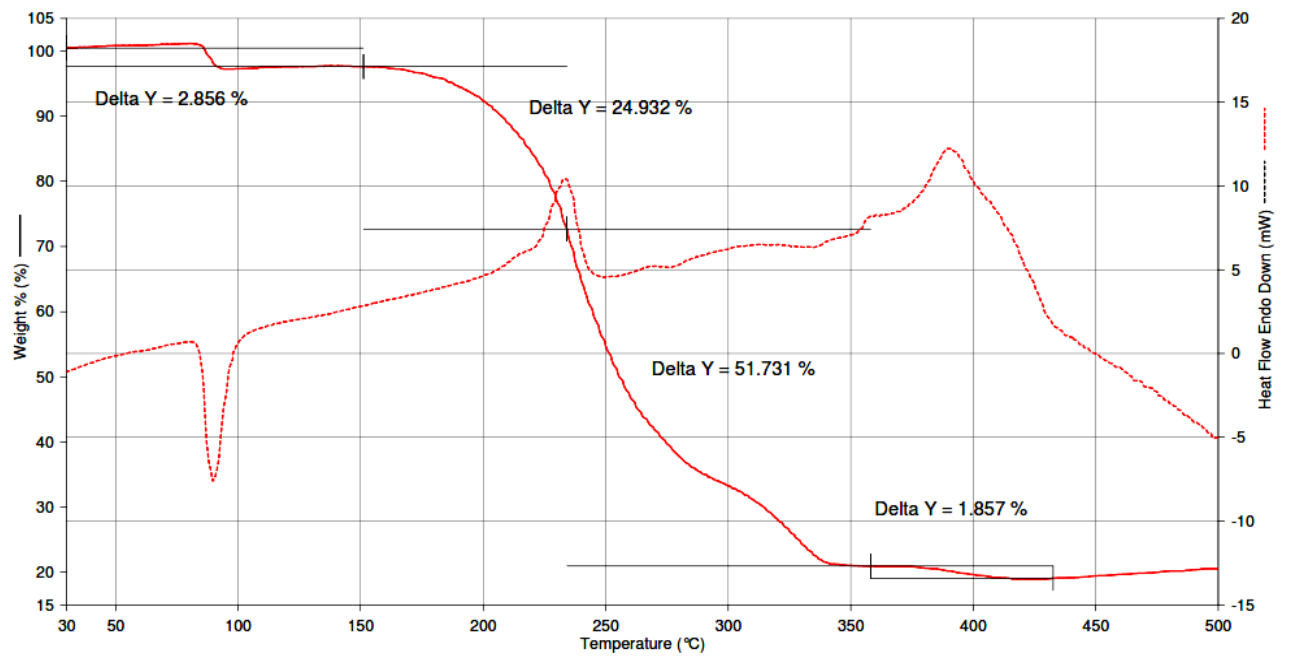

Fig. 1. The TGA-DTA of $\left[\mathrm{Mn}(\text { phen })_{3}\right]\left(\mathrm{CF}_{3} \mathrm{COO}\right)_{2} \cdot 1 \cdot 35 \mathrm{H}_{2} \mathrm{O}$ at $30-500{ }^{\circ} \mathrm{C}$

Table 2: Entity Found in $\left[\mathrm{Mn}(\text { phen })_{3}\right]\left(\mathrm{CF}_{3} \mathrm{COO}\right)_{2} \cdot 1.35 \mathrm{H}_{2} \mathrm{O}$

\begin{tabular}{lccccc}
\hline Type & $\mathrm{Mn}$ & $1.35 \mathrm{H}_{2} \mathrm{O}$ & ${ }_{2}\left(\mathrm{CF}_{3} \mathrm{COO}\right)$ & $3($ phen $)$ & ${\text { Residue } \mathrm{Mn}_{2} \mathrm{O}_{3}}$ \\
\hline Calculated & 6.5 & 2.873 & 25.444 & 60.857 & 18.664 \\
Found & 6.9 & 2.856 & 24.932 & $51.731+1.857$ & 18.624 \\
Method & AAS & TGA & TGA & TGA & TGA \\
\hline
\end{tabular}

\section{Magnetic Moment}

The effective magnetic moments of the complex calculated from molar magnetic susceptibility data which were collected on measurement for the three separated preparation were found to be $5.81,5.89$, and $5.92 \mathrm{BM}$ at $291 \mathrm{~K}$, being normal paramagnet. These reflect to the spin-only value $\left(\mu_{s}\right)$ which corresponds to five unpaired electrons in the electron configuration of $\mathrm{Mn}(\mathrm{II})$. It is normal values in an octahedral environment as observed by some literatues to be
5.89-6.16 BM for various different ligands ${ }^{18-21}$. Much lower in magnetism, however, have been reported to the molecular complex of $\left[\mathrm{Mn}(\mathrm{Val})_{2}(\text { phen })\right]^{22}$, the magnetic moment being only 5.12 BM.

\section{Electronic Spectrum}

The UV-Vis. spectrum of the powder complex as depicted in Fig. 2, demonstrates clearly three absorption bands $\left(v_{3}, v_{4}\right.$, and $\left.v_{5}\right)$ at high range of energy, $28000-40000 \mathrm{~cm}^{-1}$. Another lower shoulder at $24000-26000 \mathrm{~cm}^{-1}\left(v_{2}\right)$ and another 
bump at $17000 \mathrm{~cm}^{-1}\left(v_{1}\right)$ might establish the possible electronic transitions following Tanabe-Sugano diagram for $\mathrm{MnF}_{2}$ and comparably observed by other literatures ${ }^{18-19,23}$.

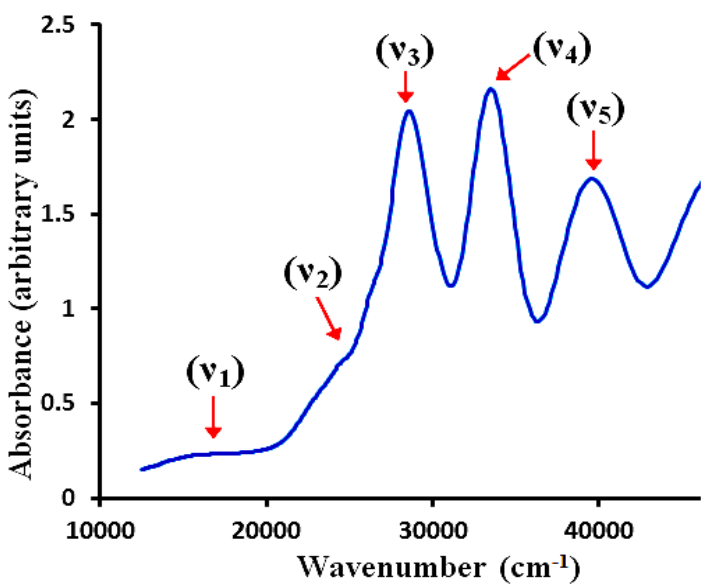

Fig. 2. UV-Vis spectrum of $\left[\mathrm{Mn}(\text { phen })_{3}\right]\left(\mathrm{CF}_{3} \mathrm{COO}\right)_{2} \cdot 1.35 \mathrm{H}_{2} \mathrm{O}$

Thus the fully high-spin state of the complex as indicated by the magnetic moment values leads to the ground state of ${ }^{6} A_{1 g}$, and since other sextet excited states are not possible there should be no spin-allowed transitions, and thus the spin-forbidden transitions to quartet states govern the electronic absorption bands. Therefore, transitions of ${ }^{6} A_{19} \rightarrow{ }^{4} T_{1 g}\left({ }^{4} \mathrm{G}\right),{ }^{6} A_{1 g} \rightarrow{ }^{4} T_{2 g}\left({ }^{4} \mathrm{G}\right),{ }^{6} A_{1 g} \rightarrow$ ${ }^{4} E_{g},{ }^{4} A_{1 g}\left({ }^{4} \mathrm{G}\right),{ }^{6} A_{19} \rightarrow{ }^{4} T_{2 g}\left({ }^{4} \mathrm{D}\right)$, and ${ }^{6} A_{1 g} \rightarrow{ }^{4} E_{g}\left({ }^{4} \mathrm{D}\right)$ are then proposed to occure at $17000 \mathrm{~cm}^{-1}\left(v_{1}\right), 24000$ $25000 \mathrm{~cm}^{-1}\left(v_{2}\right), 28000 \mathrm{~cm}^{-1}\left(v_{3}\right), 35500 \mathrm{~cm}^{-1}\left(v_{4}\right)$, and at $39500 \mathrm{~cm}^{-1}\left(v_{5}\right)$, respectively.

\section{Infrared Spectrum}

IR spectrum of this complex was collected at the range of $500-4000 \mathrm{~cm}^{-1}$ (Fig. 3). By overlaying the corresponding spectrum of TFA anion, the main purpose to assign the typical vibration bands of phenanthroline (red) might come straight forward. The broad band at about 3418 and $3433 \mathrm{~cm}^{-1}$ might be due to $-\mathrm{OH}$ stretching of $\mathrm{H}_{2} \mathrm{O}$ molecules as indicated by the formula proposed, and also observed by Shad et al., ${ }^{24}$ at about $3441 \mathrm{~cm}^{-1}$, though Kumar et al., ${ }^{25}$ assigned C-C aromatic at $3430 \mathrm{~cm}^{-1}$. Another band at 3059 and 2341-2361 $\mathrm{cm}^{-1}$ should be due to stretching vibration of $\mathrm{C}-\mathrm{H}$ bonds of phenanthroline which were reported by Chen et al., ${ }^{26}$ at $3064 \mathrm{~cm}^{-1}$, and Tosonian et al., ${ }^{27}$ at $3051-3068 \mathrm{~cm}^{-1}$.

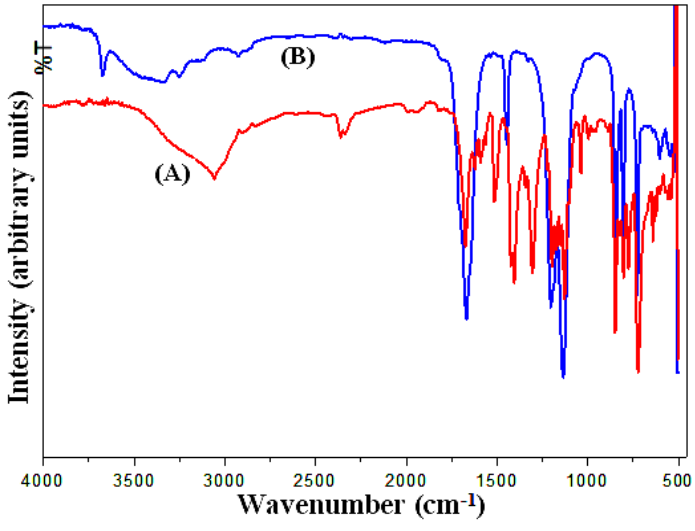

Fig. 3. IR spectrum of

$\left[\mathrm{Mn}(\text { phen })_{3}\right]\left(\mathrm{CF}_{3} \mathrm{COO}\right)_{2} \cdot 1.35 \mathrm{H}_{2} \mathrm{O}$

(A) and of TFA (B)

The typical ring modes of phenanthroline $\left(v_{\mathrm{C}-\mathrm{C}}\right.$ and $\left.\mathrm{v}_{\mathrm{C}-\mathrm{N}}\right)$ in the range of $1700-600 \mathrm{~cm}^{-1}$, might be strongly observed at 1620, 1589, 1415, 1304, and $775 \mathrm{~cm}^{-1}$, being comparably observed by Ramalakshmi et al., for the corresponding iodide ${ }^{3}$. Other stretching modes are due to TFA (blue), $v_{\mathrm{C}-\mathrm{F}}$, $v_{\mathrm{C}-\mathrm{C}}$ and $v_{\mathrm{C}-\mathrm{O}}$, being observed at $1670,1443,1203$, $1134,845,802,725$, and $602 \mathrm{~cm}^{-1}$.

\section{X-Ray Powder Diffaction and Structural Refinement}

Diffractogram of the powdered $\left[\mathrm{Mn}(\text { phen })_{3}\right]\left(\mathrm{CF}_{3} \mathrm{COO}\right)_{2} \cdot 1 \cdot 35 \mathrm{H}_{2} \mathrm{O}$ was recorded and then analysed. As shown in Fig. 4, the black signs $(+)$ are the experimental data, the red full line represents the result of refinement due to Rietica-Le Bail program performed at the range of 5-60 degree of $2 \theta$ within 75 cycles, the blue bar-lines are the expected lines of the symmetry and space group model, while the green line reflects the intensity difference between the experimental data (black) and the result of refinement (red). Clearly, the red full line does pass through almost all of the black experimental signs, as also demonstrated by almost flat green line. This suggests that the refinement of the model fitting to the experimental data is almost perfect. The detailed cell parameters of the structure are recorded in Table 3 together with similar data for some known single crystals of the same cations. Therefore, this complex synthesized in this work might be considered as triclinic symmetry of $P$ I. 


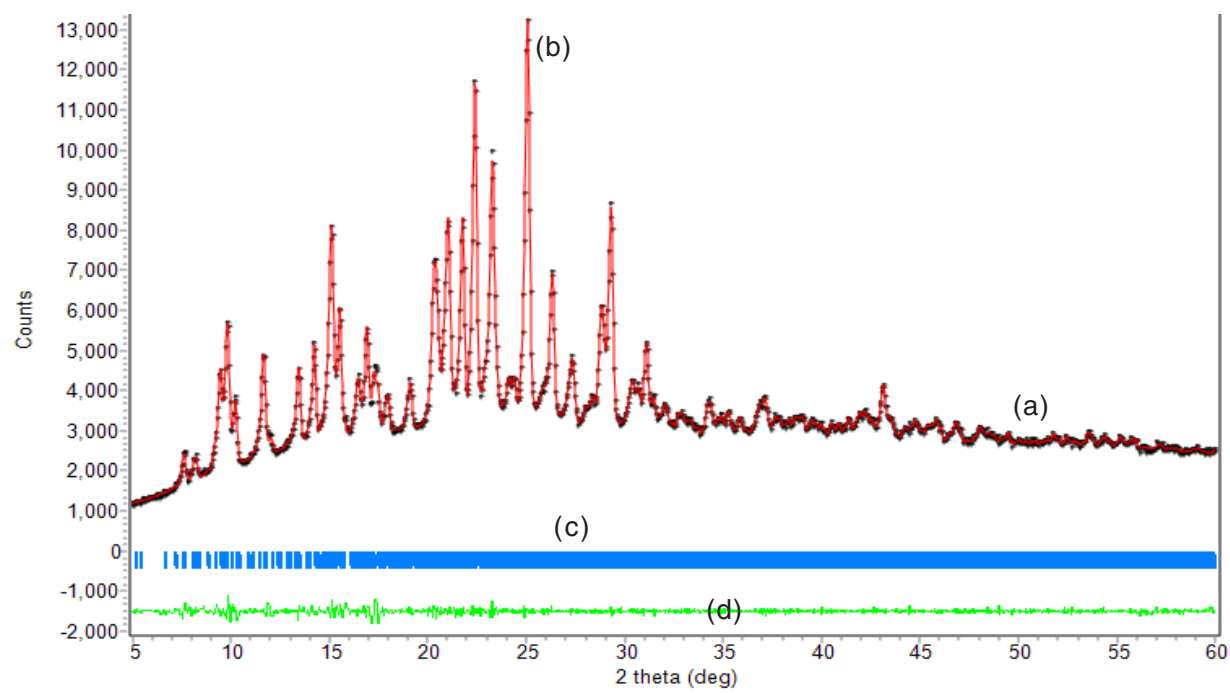

Fig. 4. XRD profile of $\left[\mathrm{Mn}(\text { phen })_{3}\right]\left(\mathrm{CF}_{3} \mathrm{COO}\right)_{2} \cdot 1.35 \mathrm{H}_{2} \mathrm{O}(\alpha$-black), the refinement on triclinic symmetry of $P I$ (b-red) with it's posision of $2 \theta$ (c-blue), and the intensity difference between the black and the red lines ( $d$-green)

Table 4: Detailed cell parameters of $\left[\mathrm{Mn}(\text { phen })_{3}\right] \mathrm{X}$, where $\mathrm{X}=(\mathrm{TFA})_{2} \cdot 1.35 \mathrm{H}_{2} \mathrm{O}(\mathrm{a})^{*},\left(\mathrm{CF}_{3} \mathrm{SO}_{3}\right)_{2} \cdot 6.5 \mathrm{H}_{2} \mathrm{O}$ $\left(\right.$ b) ${ }^{\star 28},\left(\mathrm{~B}_{6} \mathrm{H}_{7}\right)_{2}(\mathrm{c})^{14}, \mathrm{Cl}_{2}(\mathrm{~d})^{15},\left(\mathrm{I}_{3}\right)_{2}(\mathrm{e})^{3},\left(\mathrm{ClO}_{4}\right)_{2}\left(\mathrm{H}_{2} \mathrm{CO}_{3}\right)_{2}(\mathrm{f})^{5}$, and $(\mathrm{Rdtp})_{2}(\mathrm{~g})^{29}$. ("this work due to Le Bail method of Rietica program)

\begin{tabular}{|c|c|c|c|c|c|c|c|}
\hline $\begin{array}{l}\text { X } \\
\text { Symmetry } \\
\text { Space Group }\end{array}$ & $\begin{array}{c}(a)^{\star} \\
\text { Triclinic } \\
\text { PI }\end{array}$ & $\begin{array}{l}(\mathrm{b})^{\star 28} \\
\text { Triclinic } \\
\text { PI }\end{array}$ & $\begin{array}{c}(\mathrm{c})^{14} \\
\text { Triclinic } \\
\text { PI }\end{array}$ & $\begin{array}{c}(\mathrm{d})^{15} \\
\text { Tetragonal } \\
\text { I41/a (no. 88) }\end{array}$ & $\begin{array}{c}(\mathrm{e})^{3} \\
\text { Hexagonal } \\
\text { R3 (no. 148) }\end{array}$ & $\begin{array}{l}(f)^{5} \\
\text { Triclinic } \\
\quad \text { PI }\end{array}$ & $\begin{array}{c}(g)^{29} \\
\text { Monoclinic } \\
\text { C2 }\end{array}$ \\
\hline$\alpha(\AA)$ & 13.6422 & 12.6338 & 10.3131 & $35.922(1)$ & $16.456(3)$ & $12.6685(10)$ & ) $16.55(1)$ \\
\hline $\mathrm{b}(\AA \stackrel{\AA}{)}$ & 18.2792 & 17.0627 & 13.4839 & $11.8977(8)$ & $16.456(3)$ & $12.9049(2)$ & $17.50(1)$ \\
\hline$c(\AA)$ & 23.8741 & 22.4810 & 15.1132 & & $25.864(4)$ & $13.2145(10)$ & ) $17.46(1)$ \\
\hline$\alpha\left(^{\circ}\right)$ & 114.4245 & 106.8768 & 97.696 & & & $86.341(10)$ & \\
\hline$\beta\left(^{\circ}\right)$ & 94.8337 & 110.9014 & 108.324 & & & $74.337(10)$ & $93.0(1)$ \\
\hline$\gamma\left({ }^{\circ}\right)$ & 99.7977 & 99.56265 & 102.211 & & & 73.701(10) & \\
\hline $\mathrm{V}(\AA ̊)$ & 5261.6714 & 4130.4170 & 1903.92 & $15352.4(12)$ & $6066(2)$ & 1996.39(4) & 4680.0 \\
\hline Z & 1 & 1 & 2 & 16 & 6 & 4 & 4 \\
\hline \multicolumn{8}{|l|}{ Figure of merit: } \\
\hline$R_{p}$ & 1.31 & 3.67 & & & & & \\
\hline $\mathrm{R}_{\mathrm{wp}}$ & 2.39 & 7.34 & & & & & \\
\hline$R_{\exp }^{w p}$ & 0.56 & 3.61 & & & & & \\
\hline Bragg R-Factor & 0.04 & 0.09 & & & & & \\
\hline GOF & 18.00 & 4.133 & n.a. & n.a. & n.a. & n.a. & n.a. \\
\hline
\end{tabular}

\section{SEM-EDX}

The SEM photographs of $\left[\mathrm{Mn}(\text { phen })_{3}\right]$ (TFA $)_{2} \cdot 1.35 \mathrm{H}_{2} \mathrm{O}$ on various magnification reflects the high crystalinity of the complex which is also clearly demontrated by the corresponding diffractogram which shows sharp peaks. Fig. 5(d) might indicate triclinic crystal system as resolved by the Rietica program on the diffractogram. 

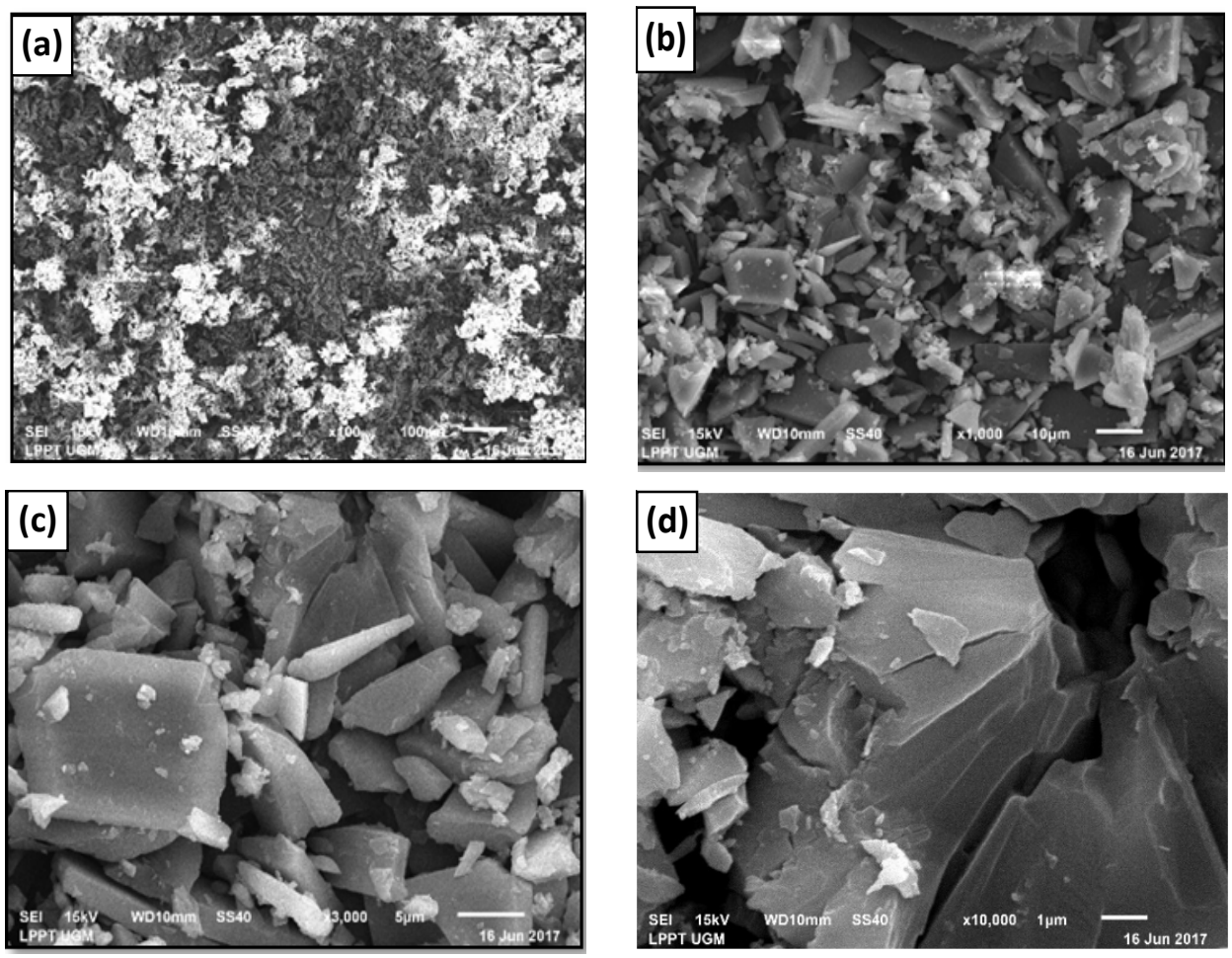

Fig. 5. SEM photographs of $\left[\mathrm{Mn}(\text { phen })_{3}\right]\left(\mathrm{CF}_{3} \mathrm{COO}\right)_{2} \cdot 1.35 \mathrm{H}_{2} \mathrm{O}$ at magnification of $100 \times(a), 1000 \times(b), 3000 x$ (c) and 10,000x (d)

The corresponding energy dispersive Xray (EDX) analysis resulted from the selected surface as shown in Fig. 6(a) strongly demonstrates the existence of all elements (Fig. 6(b)) except the hydrogen atom, and therefore, the percentage ratio

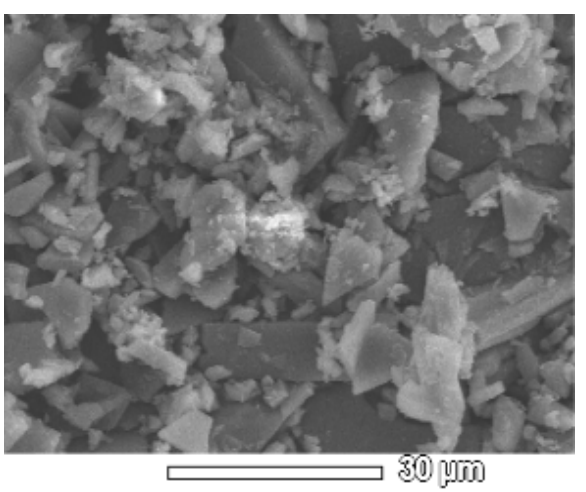

of the number of atoms, being $\mathrm{Mn}: 1(2 \%)$, C:25.7(51.43\%), N:12.7(25.56\%), O: 6.6(13.34\%), and F: $3.8(7.67 \%)$ clearly does not reflect the accurate quantitative stoichiometry.

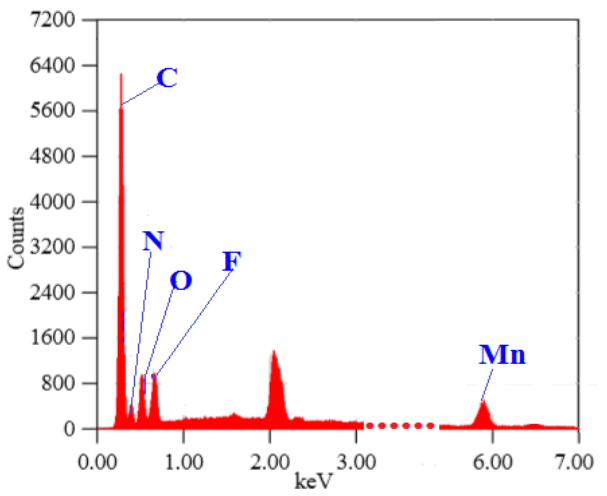

Fig. 6. The image of selected surface of $\left[\mathrm{Mn}(\text { phen })_{3}\right]\left(\mathrm{CF}_{3} \mathrm{COO}\right)_{2} \cdot 1.35 \mathrm{H}_{2} \mathrm{O}$ and its EDX analysis result showing the content of elements

\section{CONCLUSION}

The complex of $\left[\mathrm{Mn}(\text { phen })_{3}\right]\left(\mathrm{CF}_{3} \mathrm{COO}\right)_{2} \cdot 1 \cdot 35 \mathrm{H}_{2} \mathrm{O}$ has been successfully prepared and found to be normal paramagnet of high spin $\mathrm{Mn}(\mathrm{II})$. The electronic spectral property of the powdered complex might be resolved into five bands associated with the spin-forbidden transitions of the sexted ground state $\left({ }^{6} A_{1 \mathrm{~g}}\right)$ to quartet states of ${ }^{4} T_{1 g}\left({ }^{4} \mathrm{G}\right),{ }^{4} T_{2 g}\left({ }^{4} \mathrm{G}\right),{ }^{4} E_{\mathrm{g}},{ }^{4} A_{1 \mathrm{~g}}\left({ }^{4} \mathrm{G}\right),{ }^{4} T_{2 g}\left({ }^{4} \mathrm{D}\right)$, and ${ }^{4} E_{\mathrm{g}}\left({ }^{4} \mathrm{D}\right)$. 
The IR spectral properties signify the mode of vibrations characteristic for phenanthroline and TFA groups. The SEM images show high crystalinity of the powder which is also reflected by its sharp peaks of the diffractogram. Following Rietica method of Le Bail program the diffractogram was analysed to have triclinic symmetry of $P$ I space group.

\section{ACKNOWLEGMENT}

Authors thank to the Faculty of Mathematics and Natural Science (Yogyakarta State University) because for the funding, DIPA-2017 for this work.

\section{REFERENCES}

1. Ito T.; Tanaka N.; Hanazaki I.; Nagakura S. Bulletin of the Chemical Society of Japan., 1969, 42, 702-709.

2. Lee C. S.; Gorton E. M.; Neumann H. M.; Hunt Jr. H. R. Inorg. Chem. 1966, 5, 1397-1399.

3. Ramalakshmi D.; Reddy K. R.; Padmavathy D.; Rajasekharan M. V.; Arulsamy N.; Hodgson D. J. Inorganica Chimica Acta., 1999, 284, 158-166.

4. Horn C.; Scudder M.; Dance I. Cryst. Eng. Comm., 2001, 1, 1-8.

5. Kani I.; Atlier Ö.; Güven K. J. Chem. Sci., 2016, 128, 523-536.

6. Trifluoroacetic Acid. Available at: http:// www.commonorganicchemistry.com/ Common_Reagents/Trifluoroacetic_Acid/ Trifluoroacetic_Acid.htm.

7. Table of Acids with $\mathrm{Ka}$ and $\mathrm{pKa}$ Values (Compiled from Appendix 5 Chem 1A, B, C Lab Manual and Zumdahl 6th Ed.The pKa values for organic acids can be found in Appendix II of Bruice 5th Ed.). Available at: http://clas.sa.ucsb.edu/staff/Resource\% 20folder/Chem109ABC/Acid, \%20Base\% 20Strength/Table $\% 20$ of $\% 20$ Acids $\% 20 \mathrm{w}$ $\% 20 \mathrm{Kas} \% 20$ and\%20pKas.pdf.

8. Zheng Z.; Knobler C. B.; Curtis C. E.; Hawthorne M. F. Inorg. Chem., 1995, 34, 432-435.

9. Tunyogi T.; Deák A. Acta Cryst. 2010, C66, m133-m136.

10. Peedikakkal A. M. P.; Song Y. M.; Xiong R. G.; Gao S.; Vittal J. J. Eur. J. Inorg. Chem., 2010, 3856-3865.

11. Reiß G. J.; Meyer M. K. Z. Naturforsch., 2010, 65b, 479-484.

12. Robinson S. D.; Sahajpal A. J. Chem. Soc. Dalton Trans., 1997, 3349-3351.

13. Agambar C. A.; Orrell K. G. J. Chem. Soc., (A), 1969, 897-904.

14. Polyanskaya T. M.; Drozdova M. K.; Volkov V. V.; Myakishev K. G. Journal of Structural Chemistry., 2009, 50, 368-372.
15. Wang X., Z. Kristallogr., 2013, NCS 228, 5-6.

16. Figgis B. N. and Lewis, J., Modern Coordination Chemistry, Edited by Lewis, J., and Wilkins, R. G., Interscience: New York, 1960: 400.

17. Pattanayak J.; Rao V. S.; Maiti H. S.; Thermochimica Acta., 1989, 153, 193-204.

18. Singh B. K.; Mishra P.; Prakash A.; Narendar Bhojak N. Arabian Journal of Chemistry., 2012 (2017), 10, S472-S483 (to be published). https://doi.org/10.1016/j.arabjc. 2012.10.007

19. Verma R.; International Journal of Pharmaceutical Sciences and Research., 2017, 8(3), 1504-1513.

20. Devereux M.; McCann M.; Leon V.; Kelly R.; O'Shea D.; McKee V. Polyhedron., 2003, 7, 3187-3194.

21. Devereux M.; McCann M.; Leon V.; Geraghty M.; McKee V.; Wikaira J. Metal Based Drugs. 2001, 7, 275-288.

22. Fayad N. K. ; Al-Noor T. H.; Mahmood A. A.; Malih I. K. Chemistry and Materials Research., 2013, 3, 66-73.

23. Lever A. B. P., Inorganic Electronic Spectroscopy, Second Edition, Elsevier: New York, 1968: p. 293.

24. Shad H. A.; Thebo K. H.; Ibupoto Z.H.; Malik M. A.; O'Brien P.; Raftery J. Journal of Coordination Chemistry., 2011, 64, 2353-2360.

25. Kumar S. P.; Suresh R.; Giribabu K.; Manigandan R.; Munusamy S.; Muthamizh S.; Narayanan V. International Journal of ChemTech Research., 2014, 6, 3280-3283.

26. Chen H.; Xu X.-Y.; Gao J.; Yang X. J.; Lu L. D.; Wang X. Acta Phys. -Chim. Sin., 2006, 22, 856-859.

27. Tosonian S.; Ruiz C. J.; Rios A.; Frias E.; Eichler J. F., Open Journal of Inorganic Chemistry. 2013, 3, 7-13.

28. Sugiyarto K. H.; Saputra H. W.; Permanasari L.; Kusumawardani C. AIP Conference Proceedings., 2017, 1847, (040006)1- 7.

29. Drew M. G. B.; Hasan M.-I.; Hellot Y. Polyhedron., 1989, 8,1853-1854. 